\title{
Negros Bleeding-heart Gallicolumba keayi prefers dense understorey vegetation and dense canopy cover, and species distribution modelling shows little remaining suitable habitat
}

\author{
HOLLY MYNOTT $^{1^{*}}$ (D), MARK ABRAHAMS ${ }^{2}$ and DAPHNE KERHOAS ${ }^{2}$ \\ ${ }^{1}$ University of the West of England, Stoke Gifford, Bristol BS 16 IQY, UK. \\ ${ }^{2}$ Bristol Zoological Society, Clifton, Bristol BS8 3 HA, UK. \\ *Author for correspondence; email: hollymynott@hotmail.co.uk
}

(Received 28 January 2020; revision accepted 29 October 2020)

\section{Summary}

The Philippines is a global biodiversity hotspot, with a large number of threatened bird species, one of which is the 'Critically Endangered' Negros Bleeding-heart Gallicolumba keayi. The aim of this study was to investigate the habitat preference of the Negros Bleeding-heart and undertake species distribution modelling to locate areas of conservation importance based on identified suitable habitat. A survey of 94 point-counts was undertaken and eight camera traps were deployed from May to August 2018 in the Northwest Panay Peninsula Natural Park, Panay, Philippines. Habitat variables (canopy cover, understorey cover, ground cover, elevation, presence of rattan Calamus or Daemonorops spp. and pandan Pandanus sp., tree diameter at breast height, and branching architecture were measured in $5 \mathrm{~m}$-radius quadrats. To identify areas of potentially suitable habitat for the Negros Bleeding-heart, species distribution was modelled in MaxEnt using tree cover and elevation data on Panay and Negros. Using a Generalised Linear Model, Negros Bleeding-heart presence was found to be significantly positively associated with dense understorey cover and dense canopy cover. Species distribution modelling showed that the Northwest Panay Peninsula Natural Park is currently the most suitably located protected area for Negros Bleeding-heart conservation, while protected areas in Negros require further law enforcement. It is imperative that protection is continued in the Northwest Panay Peninsula Natural Park, and more survey effort is needed to identify other critical Negros Bleeding-heart populations, around which deforestation and hunting ban enforcement is strongly recommended.

Keywords: Avifauna, conservation, Columbidae, Critically Endangered, generalised linear modelling, habitat use, maximum entropy modelling, protected areas

\section{Introduction}

The Philippines is one of the top five global biodiversity hotspots, with $46 \%$ species endemism (Lee et al. 2012). However, forest cover has fallen from $90 \%$ in 1521 to $27 \%$ at present and only $11 \%$ of what remains is primary forest (Food and Agriculture Organisation of the United Nations 2015). 
This has been a contributing factor to bird species declines and the country now has the $8^{\text {th }}$ highest number of globally threatened bird species in the world (BirdLife International 2020a). The Philippines is therefore a priority area for global conservation (Paz et al. 2013).

The Negros Bleeding-heart Gallicolumba keayi is a 'Critically Endangered' colombid, found only on the islands of Panay and Negros in the Philippines. The most recent population estimate is from 2001, when 70-370 individuals were thought to remain in the wild (BirdLife International 2017). The species is threatened by habitat loss through forest conversion to agriculture or clearance for timber extraction and charcoal production. From the 1500 s to 1988, forest cover on Panay and Negros was reduced by $92 \%$ and $96 \%$, respectively, and very little primary forest remains (BirdLife International 2017, 2018b). The dove is also threatened by poaching, as it is trapped and hunted for food, or caught to keep as a pet (Cariño 2007, BirdLife International 2017). Some conservation measures are in place, e.g. patrols by forest rangers to dismantle traps and stop illegal logging in the Northwest Panay Peninsula Natural Park and northern Central Panay Mountain Range (Arkive 2007, PhilinCon 2018). Due to its small population and ongoing threats, the Negros Bleeding-heart urgently requires extensive conservation action (Bristol Zoo Gardens 2017, Gaworecki 2018).

Little is known about the biology and resource requirements of the Negros Bleeding-heart, as is the case for most species in its genus, Gallicolumba (Walker 2007). It seems to spend most of its time on the forest floor, to only use understorey plants to roost, take cover, or breed (Slade et al. 2005). It is cryptic and difficult to observe (Slade et al. 2005, Cariño 2007). Its diet consists of seeds, berries, and invertebrates (Slade et al. 2005, Cariño 2007), including fruit from Ficus and Pinanga species (Cariño 2007). It is thought to prefer lowland forest at 300-1,000 m (BirdLife International 2017 ) but it has also been reported at $>1,000 \mathrm{~m}$ on Negros, where all forest $<800 \mathrm{~m}$ has been cleared (Curio 2001), aside from some fragments at 300-900 $\mathrm{m}$ around Ban-Ban in the south-east (Biodiversity Management Bureau and Philippines Biodiversity Conservation Foundation Inc 2018). It is thought to prefer primary forest, but its ability to use secondary forest remains unclear; although reportedly detected in secondary forest on Panay, it has not been recorded in secondary forest on Negros (BirdLife International 2017). Understanding more about the species' resource requirements and habitat preference is key to implementing relevant conservation measures (Bibby et al. 2000, Begehold et al. 2015). Species presence and environmental data can be used in species distribution modelling to map where a species is most probably present (Morales et al. 2017), such that priority areas for conservation action can be identified (De Carvalho et al. 2017). The most recent study of the Negros Bleeding-heart was commissioned by Bristol Zoological Society and undertaken by the Center for Conservation Innovation (CCI), investigating its population size and habitat preference in south Negros (Bristol Zoological Society pers. comm.). Based on nine observations of this highly cryptic species in March 2016, occupancy modelling found that the dove prefers sites with dense ground vegetation coverage and high proportion of canopy cover. Furthermore, bird-habitat association modelling suggested its preference for old growth forest is likely to be influenced by the presence of ferns, fruiting and flowering trees and high ground and mid-storey vegetation cover (CCI 2016).

The aim of the current study was to investigate the habitat preference of the Negros Bleedingheart in the Northwest Panay Peninsula Natural Park and to model species distribution across its range to identify the best potential areas for conservation action. Objectives therefore were to (I) survey for the Negros Bleeding-heart using point counts, line transects, playback surveys and camera traps, collect habitat variable measurements, and assess the influence of measured habitat variables on this species' presence using Generalised Linear Modelling (GLM); (2) identify areas of potentially suitable habitat across Panay and Negros using species distribution modelling; and (3) compare Negros Bleeding-heart predicted distribution against current protected areas and Important Bird and Biodiversity Areas to identify focus areas for future conservation action. 


\section{Methods}

\section{Study site}

The study was undertaken in the forest surrounding Sibaliw field station (latitude 121.9675 ${ }^{\circ}$, longitude $11.8195^{\circ}$ ) in the Northwest Panay Peninsula Natural Park, Panay, Philippines (Figure 1). This 5,000-ha reserve encompasses the largest remaining contiguous low elevation forest across Negros and Panay, and at least half is old growth (BirdLife International 2018a). It is a protected area, where shifting cultivation, hunting, trapping or disturbing wild animals, cutting timber or gathering forest products are prohibited ( $\mathrm{Zabal}$ 2014). Various threatened species have been observed there, such as the Visayan Warty Pig Sus cebifrons (CR) (Meijaard et al. 2017), Visayan Hornbill Penelopides panini (EN) (BirdLife International 2018a), White-throated Jungle Flycatcher Vauriella albigularis (EN) and Yellow-faced Flameback Chrysocolaptes xanthocephalus (EN) (BirdLife International 2020b). Deforestation, mining, hunting, and poaching have also been observed inside the protected area (Foundation for the Philippine Environment 2018, PhilinCon 2018).

\section{Surveying for birds}

Two expeditions were undertaken in the same location within the Northwest Panay Peninsula Natural Park to survey for the Negros Bleeding-heart. Due to the extreme rarity of the species, all contacts with it, obtained using different methods, were used in this analysis to obtain information about distribution and habitat association. The first expedition was from 9 to 22 May 2018 (total 13 days observation) by Mark Abrahams, Daphne Kerhoas and Jenny Poole from Bristol Zoological Society with guides Arcel Dryden "Potpot" Fernandez and Benjamin "Jun" Tacud. Twenty $500 \mathrm{~m}$-long line transects were surveyed, with 30 point-counts placed at the start and at the end

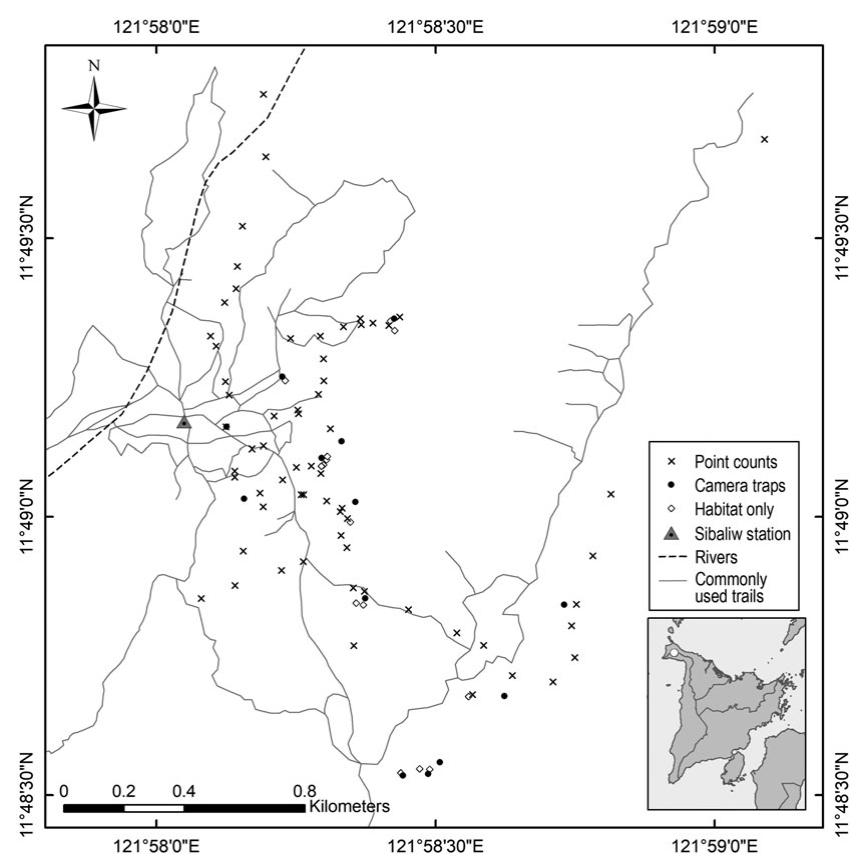

Figure 1. The location of the study site, within the Northwest Panay Peninsula Natural Park, Panay island, Philippines. Map inset shows the location of Sibaliw research station (white circle) on the island of Panay, Philippines. 
of transects. Point-counts (where an observer records all birds seen and heard from one location; Lloyd et al. 2000) lasted for 15 minutes, including a 5-minute settling period. Sightings of Negros Bleeding-heart were also recorded ad libitum, and three playback surveys were undertaken, whereby the Negros Bleeding-heart call was played while walking the transect. The second survey was from 12 July until 6 August 2018 (total 25 days observation) by Holly Mynott and the same two guides, in which 64 10-minute point-counts with no settling period were undertaken, as recommended for cryptic (Bibby et al. 2000) and terrestrial (Lee and Marsden 2008) bird species. This totals 94 point-counts, of which 80 were laid out every $200 \mathrm{~m}$ along transect lines following $<1 \mathrm{~m}$ wide trails, and 14 were not located on trails but were laid out every $200 \mathrm{~m}$ along new routes. Given the narrow width and infrequent human use of trails in this area, it is considered that this would not have overly biased results (Cornils et al. 2015). The distance between each point count location was at least $200 \mathrm{~m}$, to minimise fly-between and double counting (Lloyd et al. 2000, Lee and Marsden 2008). Point counts, when possible, were conducted within the first five hours after dawn (Reid et al. 2012) and three hours before dusk (Cornils et al. 2015), when birds are most active (Poulsen and Lambert 2000), and were not conducted in rain, fog or high winds, as this reduces bird detectability and activity (Steadman and Freifeld 1998, Paz et al. 2013, Española et al. 2016).

GPS co-ordinates of all Negros Bleeding-heart sightings from both expeditions were mapped using ArcMap v.10.4 (ESRI 2016) along with the co-ordinates of habitat measurement points. The Negros Bleeding-heart was marked as associated to any habitat data-points within $60 \mathrm{~m}$ of a sighting's co-ordinates, following protocol for the ground-foraging Grenada Dove Leptotila wellsi (Rivera-Milán et al. 2015).

Four camera traps (Bushnell 12 MP Trophy Low Glow Essential HD Trail Camera) were placed at knee height above the ground from 21 June 2018 to 14 July 2018, and four more were added from 17 July until 6 August 2018. Camera traps were moved every 7-9 days (Rowcliffe et al. 2011) for a total of 161 camera-days. Camera traps were placed using purposive sampling to evenly cover the accessible areas and also focus on locations at which guides had seen the dove previously (Treves et al. 2010).

\section{Measuring habitat}

Ninety-three circular quadrats of $5-\mathrm{m}$ radius $\left(78.54 \mathrm{~m}^{2}\right.$ area) were surveyed to measure habitat variables, a figure assumed to be representative of surrounding rainforest habitat (Peh et al. 2006, Posa and Sodhi 2006, Reid et al. 2012, Pangau-Adam et al. 2015). Sixty-four of these quadrats overlapped with point count locations and 13 with camera trap locations (Figure 1 ). The remaining 16 did not coincide with another measurement point. All 93 quadrats were associated to any Negros Bleeding-heart sightings recorded within $60 \mathrm{~m}$ of them (Rivera-Milán et al. 2015), as stated in the bird survey methods. At each quadrat, GPS co-ordinates and an elevation reading were taken using a Garmin GPS unit (Garmin eTrex 30x), because altitude can be a major predictor of occurrence in forest bird species (Bibby 2000, Dallimer and King 2007, Paz et al. 2013). Tree diameter at breast height (DBH) was measured in three categories: o to $\leq 25 \mathrm{~cm}$ (band I), $>25$ to $\leq 50 \mathrm{~cm}$ (band 2), and $>50 \mathrm{~cm}$ (band 3), following other bird-habitat studies (Paz et al. 2013, Zarones et al. 2013). Tree height was measured using a protractor-clinometer and trigonometry (Flinn Scientific 2016). Branching architecture was noted following the guidelines in Bibby et al. (2000) to indicate recent forest disturbance levels, and proportion of trees with a closed and regenerating forest structure was calculated. Canopy cover was estimated using a spherical densiometer (Forest Densiometers, Rapid City, ND) (Peh et al. 2006, Posa and Sodhi 2006, Reid et al. 2012), by calculating the mean canopy percentage cover from the north, east, south, and west value. Percentage vegetation cover at ground level ( $<1 \mathrm{~m})$ ("percentage ground cover") and understorey cover at $1.5 \mathrm{~m}$ above the ground were estimated by eye by the first author (Posa and Sodhi 2006, Pangau-Adam et al. 2015). The presence or absence of any species of pandan Pandanus sp. and rattan (Calamus or Daemonorops spp.; Tesoro 2002) was noted, similar to a previous Negros Bleeding-heart study (CCI 2016). 
Distance to Sibaliw station was calculated using ArcMap, because it has been shown that species diversity can be higher closer to field stations (Campbell 2011).

\section{Data Analysis}

Habitat preference: Data were analysed with a Binomial Generalised Linear Model (Zuur et al. 2013) in R v.3.6.I (R Core Team 2019), in which the dependent variable was presence/absence of the Negros Bleeding-heart. Following Zuur et al. (2013), no outliers were found in the dataset. Multicollinearity was tested for using variance inflation factor (Zuur et al. 2013). Tree height was found to be highly correlated with $\mathrm{DBH}(\mathrm{R}=0.67)$ using a pair plot (Zuur et al. 2013), hence it was dropped from the model ( $\mathrm{O}^{\prime}$ Brien 2007, Zuur et al. 2010). All the explanatory variables were scaled to enable model convergence and effect size comparisons (Zuur et al. 2013, Abrahams et al. 2017). A full model incorporating all variables was created using the $\mathrm{R}$ function $\mathrm{glm}$, following which automated model creation was conducted using the $\mathrm{R}$ function dredge, in the $\mathrm{R}$ package "MuMIn" version 1.43.6 (Bartoń 2015). Models with $\triangle \mathrm{AIC} \leq 2$ were averaged using the $\mathrm{R}$ function model.avg, as described in Feld et al. (2016) and used in other bird-habitat studies (e.g. Xu et al. 2017, Lewis et al. 2018). The GLM was run using the following covariates: ground cover, understorey cover, canopy cover, elevation, proportion of trees with a closed forest branching structure, proportion of trees with a regenerating forest branching structure, presence of pandan, presence of rattan, distance to Sibaliw research station, and the number of trees in each of DBH band 1,2 and 3 at each site.

Species distribution modelling: Negros Bleeding-heart distribution was modelled in MaxEnt v.3.4.I (Phillips et al. 2017) for maximum entropy species distribution modelling (Merow et al. 2013, Morales et al. 2017). Two environmental predictor inputs were used. The first was a map of tree cover, which is defined as canopy closure for all vegetation taller than $5 \mathrm{~m}$, and encoded as a percentage output per grid cell, at 30-m resolution (Hansen et al. 2013). The second was an elevation map at $90 \mathrm{~m}$ resolution (PhilGIS 2007), as the Negros Bleeding-heart has been reported to occur in lowland forests up to 1,00o m (BirdLife International 2017). While the co-ordinates of all 31 Negros Bleeding-heart sightings were included in the model, due to the tree cover and elevation map resolutions, 17 presence records were used for training and five were used for testing. Feature types, selected automatically by MaxEnt, as is the program default, were hinge, linear and quadratic. The regularization parameter on MaxEnt was set to 1.5, which is a suitable figure to reduce over-fitting compared to the default setting of $I$ (Radosavljevic and Anderson 2014); lower settings risk loss of predictive ability with independent test data, and higher settings can falsely mark areas as suitable (Radosavljevic and Anderson 2014). The threshold rule applied was "maximum test sensitivity plus specificity" (Liu et al. 2005), and the true skill statistic was calculated in Excel. The background was cropped to include only the islands of the species' known range (Merow et al. 2013), Panay and Negros. The model was run with 10,00o background points, which has been evaluated as high-performing number (Phillips and Dudik 2008) and used in studies on cryptic insect species (Zhao et al. 2019). Finally, the locations of Important Bird and Biodiversity Areas (IBAs) (BirdLife International 2008) were mapped over the species distribution modelling results to enable informed conservation actions.

\section{Results}

The Negros Bleeding-heart was recorded 31 times in total. Camera traps recorded the Negros Bleeding-heart on three separate occasions out of 161 camera-days (21, 22 and 24 June 2018) at the same location. Hunters were also recorded on two occasions at the same location by the camera traps. 


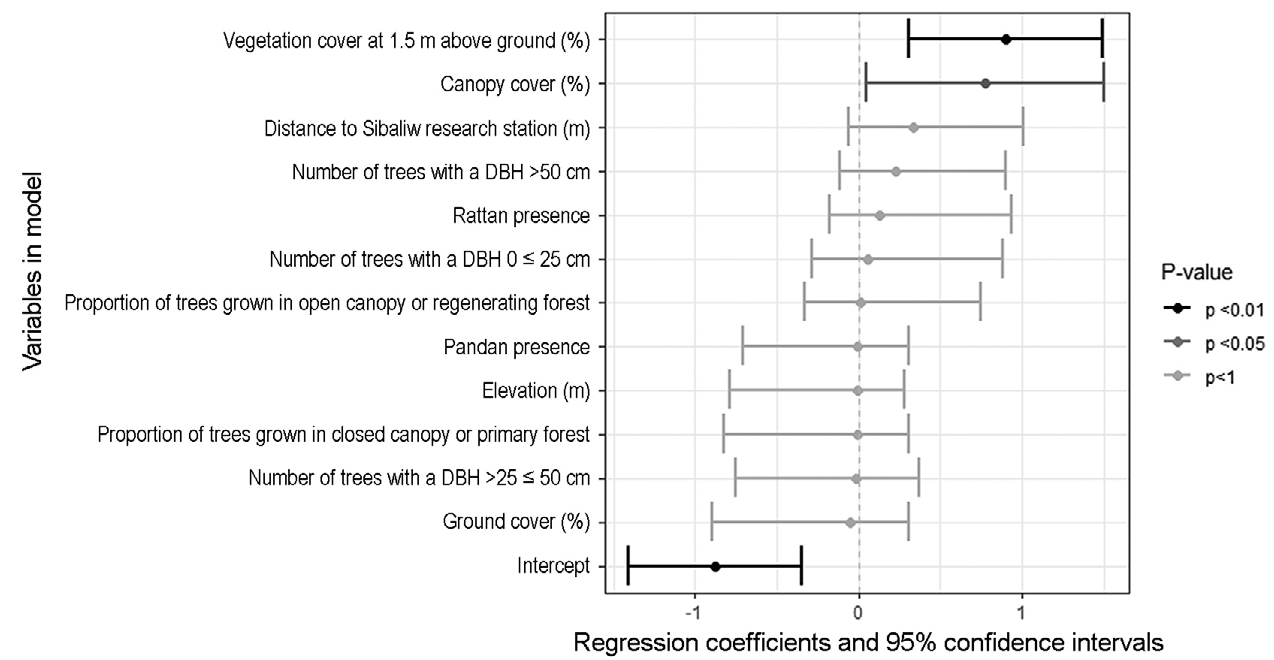

Figure 2. Coefficients and $95 \%$ confidence intervals of explanatory variables from Generalised Linear Model.

\section{Habitat preference}

All Negros Bleeding-heart sightings were associated with habitat plots measured (i.e. 31 out of the 93 quadrats). The full averaged GLM results (Tables $S_{1}$ and $S_{2}$ in the online supplementary material) showed that understorey cover at $1.5 \mathrm{~m}$ above the ground had significant impact on Negros Bleeding-heart presence $(P=0.001)$, showing a positive association with dense understorey cover. Canopy cover was also found significant $(P=0.003)$, showing that Negros Bleeding-heart presence had a positive association with dense canopy cover. Coefficients and $95 \%$ confidence intervals of the explanatory variables in the GLM were graphed (Figure 2). The predicted effect sizes of significant habitat variables on Negros Bleeding-heart presence for the top-performing model within the $\triangle \mathrm{AIC} \leq 2$ averaged model were graphed (Figure 3 ), and found to be similar to the other top-performing models of $\triangle \mathrm{AIC} \leq \mathrm{I}$ in the set (Figure $\mathrm{S} I$ ).

\section{Species distribution modelling}

The AUC value of the training and test datasets were 0.969 and 0.984 , respectively, and the true skill statistic value was 0.9609 , indicating a high level of accuracy in the model prediction (Fielding and Bell 1997). Response curves showed a positive effect of increasing tree cover on habitat suitability and an optimal elevation peaking around $600 \mathrm{~m}$ (figure 4).

The species distribution modelling in MaxEnt produced relative habitat suitability probabilities ranging from $o$ to 1 , with the most suitable habitat on Panay located around the Northwest Panay Peninsula Natural Park and the Central Panay Mountain Range, and the most suitable habitat in Negros found in the North Negros Natural Park, on the slopes of an area just outside the Mt Kanlaon Natural Park, and in an area to the south half-covered by Cuernos de Negros IBA (Figure 5). Most areas seem fragmented and few are highly suitable, particularly on Negros. Furthermore, there are large unsuitable patches in high elevation areas due to this species' preference for lower elevation forest at the centres of the North Negros Natural Park, Mount Kanla-on Natural Park, Cuernos de Negros and the Central Panay Mountain Range. 

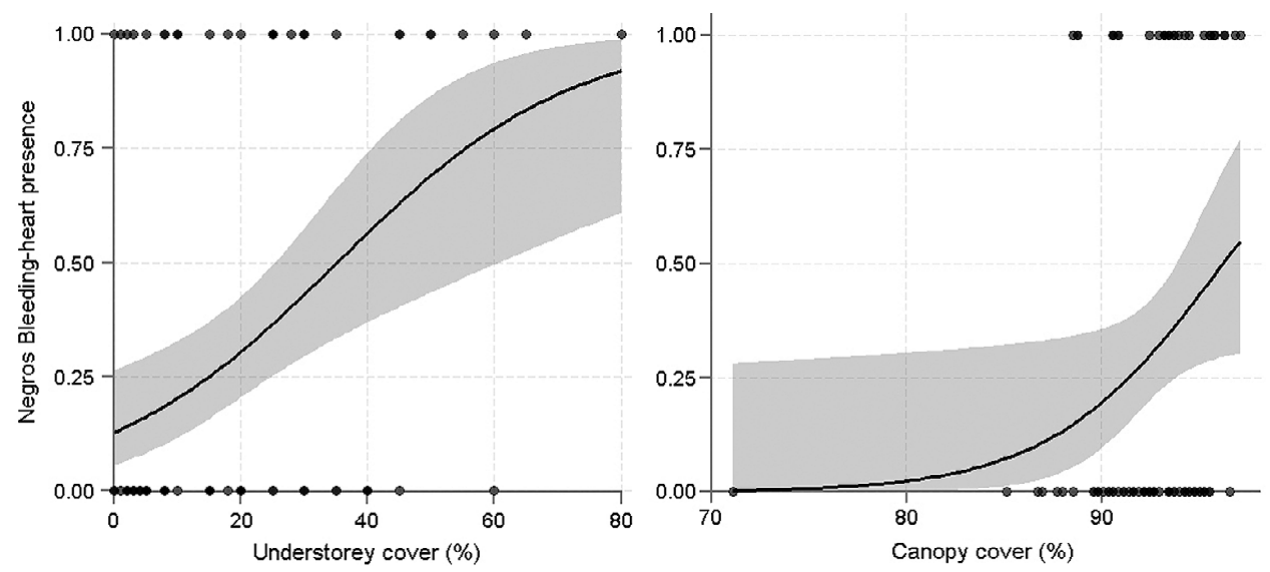

Figure 3. Effect predictions for significant variables on Negros Bleeding-heart presence from the top-performing Generalised Linear Model before averaging $(\triangle \mathrm{AIC}=0)$. Shaded areas show upper and lower confidence limits, and dots show data points from which predictions were calculated.
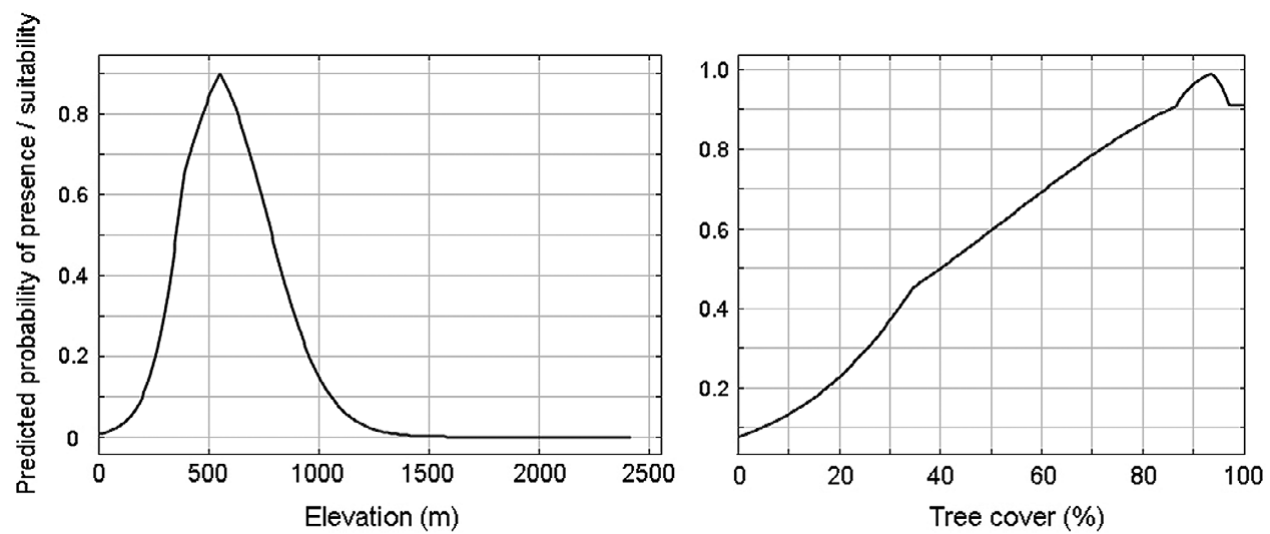

Figure 4. Response curves of the two environmental variables, tree cover and elevation, in a Maxent species distribution model for Negros Bleeding-heart.

\section{Discussion}

\section{Habitat preference}

Understorey cover, mostly by herbs, shrubs, and ferns, was significantly associated with Negros Bleeding-heart presence. This association has been found for other bird species, postulated to be because dense understorey provides a balance of both attractive food resources and cover to escape from predators (Lima and Dill 1990, Reid et al. 2004, Smith et al. 2017). The Luzon Bleeding-heart Gallicolumba luzonica, a close relative to the Negros Bleeding-heart, is reported to use thick undergrowth to escape predators (Del Hoyo et al. 1997), and the Negros Bleeding-heart itself is known to forage on the ground, tossing aside leaf litter in its search for food (Curio 2001). However, understorey cover could also relate to forest quality. Dense shrub or herb cover can be characteristic 


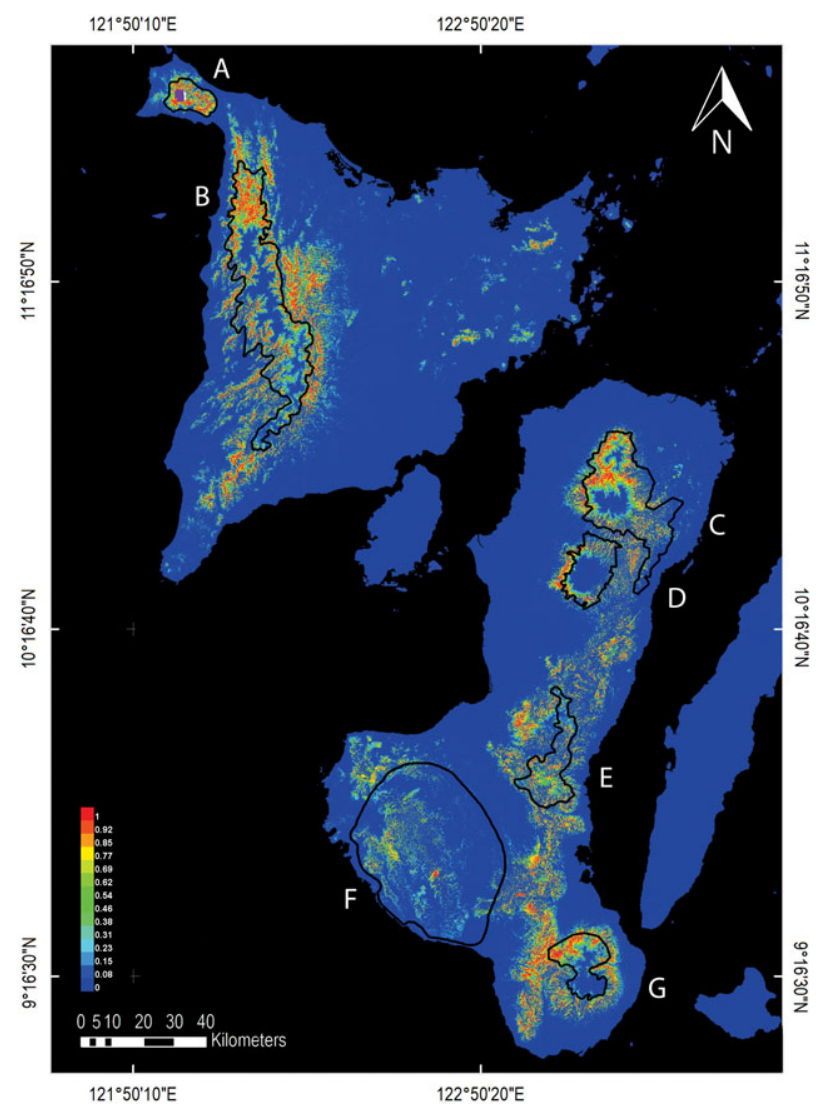

Figure 5. Species distribution modelling of the Negros Bleeding-heart on Panay and Negros. Scale is from white to dark grey, with relative suitability for Negros Bleeding-heart from 1 to o, indicating high and low suitability respectively. Locations of Important Bird Areas are shown as black outlines. On Panay: (A) Northwest Panay Peninsula Natural Park (BirdLife International 2018a), (B) Central Panay Mountain Range (BirdLife International 2018b). On Negros: (C) North Negros Natural Park (BirdLife International 2018c), (D) Mount Kanla-on Natural Park (BirdLife International 2018d), (E) Ban-ban (BirdLife International 2018e), (F) Southwestern Negros (BirdLife International 2018f), (G) Cuernos de Negros (BirdLife International 2018g).

of secondary forests (Cochard et al. 2018), therefore suggesting that the Negros Bleeding-heart could be able to inhabit secondary forest, as found in other ground doves which also favour primary forest (Blanvillain et al. 2002). However, the present study also identified a preference for closed canopy forest, which is characteristic of primary forest (Shoo et al. 2016). A preference for primary forest is supported by numerous other studies showing that terrestrial birds like the Negros Bleeding-heart are often the species most affected by loss of primary forest (Sieving et al. 1996, Newmark et al. 2010, Powell et al. 2013, Bradfer-Lawrence et al. 2018). Such species are often unable to inhabit secondary forest (Peh et al. 2005, Stratford and Stouffer 2013), and even welldeveloped secondary forest, which also has dense canopy cover, is often less biodiverse than its primary counterparts (Chadzon et al. 2009). The ability of the Negros Bleeding-heart to use secondary forest remains unclear (BirdLife International 2017). Some secondary forest patches in this study have been recorded, but they were small and surrounded by primary forest, and therefore the dove might move between patches of both forest types to exploit resources but rely 
mainly on primary forest, as postulated by Peh et al. (2005) for bird species in a Malaysian forest. Potential inability to use exclusively secondary forest could therefore explain why the dove is not found in some areas of secondary forest on Negros (BirdLife International 2017).

The habitat preference findings of this study are preliminary and could be improved by a greater quadrat size for habitat measurement and more accurate linkage of point count results to habitat plots. While 6o-m association distance has been used in other studies on similar species (Rivera-Milán et al. 2015), it adds uncertainty to the results. However, since little is known about this highly threatened species, the findings are still potentially important in directing conservation action (Huon et al. 2015). Research into the tolerance of secondary forest by Negros Bleeding-heart is strongly recommended, particularly considering how little primary forest remains across its range (BirdLife International 2017).

\section{Species distribution modelling}

Species distribution modelling shows that suitable habitat is found in forested, low-elevation areas. Such areas have been reported in previous studies (BirdLife International 2017) to be Negros Bleeding-heart requirements. The suitability of forested areas supports the findings of the GLM in regard to the importance of understorey cover and canopy cover. However, elevation was found not to be a significant variable in the GLM. This may be because the range measured was all suitably low elevation habitat, ranging from 192 to $622 \mathrm{~m}$. The species distribution model also highlights that large proportions of the core areas inside many IBAs and protected areas may be less suitable than previously thought. This is particularly so within the protected areas of the North Negros Natural Park and Mt Kanla-on Natural Park, and the unprotected IBAs of the Central Panay Mountains and Cuernos de Negros, with some edge areas appearing more suitable than within the core areas. This is a particular concern, because the edges of reserves are often subject to abiotic and biotic edge effects that can reduce habitat quality, particularly for understorey birds (Pohlman et al. 2007, Neate-Clegg et al. 2016), and to greater human pressures, such as encroachment by agriculture, charcoal logging or hunting by those living on the borders (Pedregosa-Hospodarsky et al. 2009).

The model shows a significant amount of potentially suitable habitat near the eastern border of the North Negros Natural Park, which is one of the only remaining lowland forest sites on Negros, although largely secondary (BirdLife International 2018c). The tree cover map does not distinguish between primary and secondary forest (Hansen et al. 2013). The Negros Bleeding-heart has been reported there (BirdLife International 2018c), but has not been found in bird surveys during the past 20 years (Hamann 2002, Pedregosa-Hospodarsky et al. 2009), and the park is under pressure from illegal logging and snare hunting (Pedregosa-Hospodarsky et al. 2009). Modelling also shows a small area of suitable habitat along the boundary of Mt Kanla-on Natural Park, where the Negros Bleeding-heart was seen in 1991 (Brooks et al. 1992), but not since (Cariño 2007). Furthermore, most of the park's forest is $>1,000 \mathrm{~m}$ asl. (Brooks et al. 1992), which exceeds the estimated altitudinal limit of the dove based on previous surveys (BirdLife International 2017). Any populations just outside the boundary would be threatened by the continued deforestation on the lower slopes (BirdLife International 2018d), demonstrating that the current boundaries of Mt Kanla-on Natural Park may not be adequate to protect this species. Of the non-protected IBA sites, the largest indicated suitable area is around the Cuernos de Negros IBA, half within the reserve and the rest just outside the borders. Cariño (2007) recorded the dove several times near the border, and it was reported inside the IBA in the CCI (2016). It has also been recorded on www.ebird.org by two observers in 2019 at Sibulan, within the IBA. However, the CCI survey lasted only four days in 2016, and another nine-week survey in the same area in 2017 failed to encounter the dove (Cantero-Sanchez 2018). Furthermore, Bristol Zoological Society studied the wider Cuernos de Negros IBA in 2014-2017, obtaining a minimum of 347 camera trap days, and the Negros Bleeding-heart was never sighted (Falcidia 2017). It is therefore possible that the dove may not occur at high density or even be present in much of the Cuernos de Negros IBA, given the high elevation of this area. Hence, this may not be a priority site in the conservation of Negros Bleeding- 
heart. As far as we are aware, there are no other recent sightings of this species in Negros, but the recent publication of a conservation action plan for Negros (Biodiversity Management Bureau and Philippines Biodiversity Conservation Foundation Inc 2018) shows promise for future collaboration between NGOs to organise effective conservation initiatives.

Based on the number of sightings obtained in this study compared to other recent studies on Negros, and from the species distribution modelling results, the Northwest Panay Peninsula Natural Park appears to be the most effective currently protected area on Panay and Negros for the Negros Bleeding-heart. It is therefore a critical stronghold for the species, requiring continued conservation action, which is ongoing (PhilinCon 2018). Furthermore, there appear to be large areas of potentially suitable habitat for the Negros Bleeding-heart around and within the Central Panay Mountain Range, although this is not yet a formally protected area (Haribon Foundation 2016). The Negros Bleeding-heart has been reported there by several sources (De Soye 1997, Pedregosa-Hospodarsky 2008, Masur 2010, Schwarz 2014), but to our knowledge, no population survey has been undertaken. Therefore, this area is a priority for survey effort, particularly considering the likely extreme rarity of the Negros Bleeding-heart on Negros.

Finally, species distribution modelling shows that the suitable habitat patches throughout Panay and Negros are not well connected. Habitat connectivity is important for maintaining small populations (Kramer et al. 2009, Spigler et al. 2017, Gómez-Sánchez et al. 2018) and therefore the creation of forest corridors to connect fragments (Jansen 2005, Barzan et al. 2015) could benefit the Negros Bleeding-heart, particularly considering that understorey birds are reluctant to cross non-forested patches (Bradfer-Lawrence et al. 2018). However, certain fragments are very distant, hence forest corridor creation may not be immediately practical at large scales, and work that can be implemented more quickly may be required. To that end, an option which is increasingly used to support in situ conservation of small animal populations is captive breeding, with the aim of future reintroduction (Braverman 2014). Negros Bleeding-heart is currently bred in captivity at the Centre for Tropical Conservation Studies (CENTROP) in Negros, and by Talarak Foundation Incorporation, with an overall captive population of 88 individuals in June 2020 (Fernando 'Dino' Guttierez at Talarak, and Lou-Jean Cerial at CENTROP pers. comm.). We recommend that this work continues alongside in situ conservation measures.

\section{Model comparison}

The GLM and species distribution modelling approaches respectively offer fine- and large-scale explorations of Negros Bleeding-heart distribution. We selected tree cover and elevation as variables in the species distribution modelling because the Negros Bleeding-heart has been reported to occur in lowland forests up to $1,000 \mathrm{~m}$ (BirdLife International 2017). Ideally, understorey cover, the most significant variable in the GLM, would have been used in the species distribution modelling, but large-scale datasets of understorey cover are not available. Elevation may act as a proxy for other, unmapped, biotic, and abiotic variables, rather than directly impacting the Negros bleedingheart (Hof et al. 2012). In addition, the tree cover dataset used does not distinguish forest quality or between primary and secondary forest (Hansen et al. 2013). Whilst it is unknown if the Negros Bleeding-heart requires primary forest (BirdLife International 2017), if this is the case, then our species distribution modelling maps (Figure 5), which already indicate very little remaining suitable habitat, may be an optimistic overestimate.

Finally, this survey was designed for habitat preference assessment rather than an occupancy type analysis. We therefore did not utilise repeated sampling in a way that would allow us to make use of species distribution modelling approaches that use known absences (Lahoz-Monfort et al. 2014). The authors recognise that detection of the Negros Bleeding-heart is not perfect and are conducting systematically repeated sampling as part of future research to enable modelling of the detection function and use of occupancy detection modelling. 


\section{Conclusion}

The Negros Bleeding-heart has a preference for dense understorey vegetation and dense canopy cover, and the largest area of suitable habitat currently seems to be in the Northwest Panay Peninsula Natural Park on Panay. On Negros, Mt Kanla-on Natural Park may contain habitat for the Negros Bleeding-heart, although the elevation is high, and further protection of the North Negros Natural Park's eastern border is needed. Though law enforcement in remote areas entails logistical and security challenges, it is essential that laws against deforestation and hunting in all remaining population refuges are strictly enforced in order to halt the decline in numbers. In addition, we recommend that future research effort focuses on two areas: 1 ) to establish the degree to which the Negros Bleeding-heart requires primary rather than secondary forest, and 2) to assess its population status in the Central Panay Mountain Range and the North Negros Natural Park, which may be suitable sites for Negros Bleeding-heart conservation.

\section{Supplementary Material}

To view supplementary material for this article, please visit http://dx.doi.org/10.1017/ So959270920000611.

\section{Acknowledgements}

The authors thank everyone at PhilinCon for making this study possible: guides Potpot Fernandez and Jun Tacud, Rhea Santillan for helping organise the logistics, the Sibaliw research station staff, and porters, including Momel, Ulysses and Dudong, Professor Dr Eberhard Curio (PhilinCon President) and Justine Magbanua. Our thanks go to Christian Schwarz (PhilinCon) for helpful comments on the manuscript, and to Dr Tim Bray for species distribution modelling advice. We especially thank D. Hending (University of Bristol/Bristol Zoological Society), for cleaning the xeno-canto calls for the playbacks. We are grateful to the local barangays and the Department of Environment and Natural Resources (DENR) for permission to conduct research in the Northwest Panay Peninsula Natural Park. We also thank two anonymous reviewers for their thoughtful and helpful comments and suggestions. This research was financially supported by Bristol Zoological Society, Airbus and the University of the West of England.

\section{References}

Abrahams, M. I., Peres, C. A. and Costa, H. C. M. (2017) Measuring local depletion of terrestrial game vertebrates by centralplace hunters in rural Amazonia. PLoS One 12(10): e0186653.

Arkive (2007) Negros Bleeding-heart (Gallicolumba keayi). Available at: https:// www.arkive.org/negros-bleeding-heart/ gallicolumba-keayi/ [accessed 7 November 2018].

Bartoń, K. (2015) MuMIn: Multi-model inference. $R$ package version I (15): I. Available at: http://CRAN.R-project.org/package $=$ MuMIn [accessed 29 November 2019].

Barzan, F. R., Baigorria, J. M. E. and Bó, R. F. (2015) Bird community diversity in three habitat types in an ecological corridor in the Atlantic Forest of Misiones province, Argentina. Trop. Conserv. Sci. 8: 955-974.

Begehold, H., Rzanny, M. and Flade, M. (2015) Forest development phases as an integrating tool to describe habitat preferences of breeding birds in lowland beech forests. J. Ornithol 156: 19-29.

Bibby, C., Marsden, S. and Fielding, A. (200o) Bird-habitat studies. Pp. 98-113 in C. Bibby, M. Jones and S. Marsden, eds. Bird Surveys. Cambridge, UK: BirdLife International.

Biodiversity Management Bureau and Philippines Biodiversity Conservation Foundation Inc (2018) Negros Island Biodiversity Strategy and Action Plan. Bacolod, 
Philippines: Biodiversity Management Bureau and Philippines Biodiversity Conservation Foundation Inc.

BirdLife International (2008) The impact of Important Bird Area Directories. Available at: http://datazone.birdlife.org/sowb/case study/the-impact-of-important-bird-areadirectories [accessed 6 December 2018].

BirdLife International (2017) Gallicolumba keayi. In The IUCN Red List of Threatened Species 2017. Available at: http://dx.doi.org/ 10.2305/IUCN.UK.2018-2.RLTS.T22690988 A130328535.en [accessed 20 March 2018].

BirdLife International (2018a) Northwest Panay Peninsula Natural Park. Available at: http://datazone.birdlife.org/site/fac tsheet/northwest-panay-peninsula-naturalpark-iba-philippines [accessed 26 October 2018].

BirdLife International (2018b) Central Panay Mountains. Available at: http://datazone. birdlife.org/site/factsheet/central-panaymountains-iba-philippines [accessed 26 October 2018].

BirdLife International (2018c) North Negros Natural Park. Available at: http://datazone. birdlife.org/site/factsheet/north-negrosnatural-park-iba-philippines [accessed 26 October 2018].

BirdLife International (2018d) Mt Kanla-on Natural Park. Available at: http:// datazone.birdlife.org/site/factsheet/9763 [accessed 26 October 2018].

BirdLife International (2018e) Ban-ban. Available at: http://datazone.birdlife.org/ site/factsheet/ban-ban-iba-philippines [accessed 26 October 2018].

BirdLife International (2018f) Southwestern Negros. Available at: http://datazone.birdlife. org/site/factsheet/9765 [accessed 26 October 2018].

BirdLife International (2018g) Cuernos de Negros. Available at: http://datazone.bird life.org/site/factsheet/cuernos-de-negrosiba-philippines [accessed 26 October 2018].

BirdLife International (2020a) Country profile: Philippines. Available at: http://www. birdlife.org/datazone/country/philippines [accessed 17 June 2020].

BirdLife International (2020b) IUCN Red List for birds. Available at: http://www.birdlife. org [accessed 26 June 2020].
Blanvillain, C., Florent, C. and Thenot, V. (2002) Land birds of Tuamotu Archipelago, Polynesia: relative abundance and changes during the 2oth century with particular reference to the Critically Endangered Polynesian ground-dove (Gallicolumba erythroptera). Biol. Conserv. 103: 139-149.

Bradfer-Lawrence, T., Gardner, N. and Dent, D. H. (2018) Canopy bird assemblages are less influenced by habitat age and isolation than understory bird assemblages in Neotropical secondary forest. Ecol. Evol. 8: 5586-5597.

Braverman, I. (2014) Conservation without nature: the trouble with in situ versus ex situ conservation. Geoforum 51: 4757.

Bristol Zoo Gardens (2017) Negros Bleedingheart Dove. Available at: https://www. bristolzoo.org.uk/save-wildlife/conserva tion-and-research/negros-bleeding-heartdove-project [accessed 7 November 2018].

Brooks, T. M., Evans, T. D., Dutson, G. C. L., Anderson, G. Q. A., Asane, D. C., Timmins, R. J. and Toledo, A. G. (1992) The conservation status of the birds of Negros, Philippines. Bird Conserv. Internatn. 2: 273-302.

Campbell, G., Kuehl, H., Diarrassouba, A., N'Goran, P. K. and Boesch, C. (2011) Longterm research sites as refugia for threatened and over-harvested species. Biol. Lett. 7 : $723-726$.

Cantero-Sanchez, V. (2018) Conservation of endemic birds in the Island of Negros, Philippines: A focal species approach. MSc thesis. Edinburgh, UK: Edinburgh Napier University.

Cariño, A. B. (2007) Conservation of the Critically Endangered Negros Bleeding Heart Pigeon Gallicolumba keayi on the Island of Negros, Philippines. Dumaguete City, Philippines: Silliman University Center for Tropical Conservation Studies.

CCI (2016) Predictive modeling of the Negros Bleeding-Heart Pigeon and its habitat: Implications for management. Unpublished report for Bristol Zoo Gardens. Philippines: Center for Conservation Innovation.

Chadzon, R. L., Peres, C. A., Dent, D., Shiel, D., Lugo, A. L., Lamb, D., Stork, N. E. and Miller, S. E. (2009) The potential for species conservation in tropical secondary forests. Conserv. Biol. 23: 1406-1417. 
Cochard, R., Van, Y. and Ngo, D. (2018) Determinants and correlates of above-ground biomass in a secondary hillside rainforest in Central Vietnam. New Forest 49: 429-455.

Cornils, J. S., Riedl, I., Fricke, J., Katz, M. and Schulze, C. H. (2015) Population density and habitat preferences of the Blackcheeked ant-tanager Habia atrimaxillaris. Bird Conserv. Internatn. 25: 306-321.

Curio, E. (2001) Taxonomic status of the Negros bleeding-heart Gallicolumba keayi from Panay, Philippines, with notes on its behaviour. Forktail 17: 13-19.

Dallimer, M. and King, T. (2007) Habitat preferences of the forest birds on the island of Principe, Gulf of Guinea. Afr. J. Ecol. 46: 258-266.

De Carvalho, D. L., Sousa-Neves, T., Cerqueira, P. V., Gonsioroski, G., Silva, S. M., Silva, D. P. and Santos, M. P. D. (2017) Delimiting priority areas for the conservation of endemic and threatened Neotropical birds using a niche-based gap analysis. PLoS One 12(2): e0171838.

De Soye, Y. (1997) Conservation research on Panay [Philippines]: key facts of preliminary surveys [1997]. Technical Journal of Philippine Ecosystems and Natural Resources. Available at: http://agris.fao.org/agris-sea $\mathrm{rch} /$ search.do ?recordID $=\mathrm{PH} 2000100072$ [accessed 20 November 2018].

Del Hoyo, J., Elliott, A. and Sargatal, J., eds. (1997) Handbook of the Birds of the World. Vol. 4. Barcelona, Spain: Lynx Edicions.

Española, C. P., Collar, N. J., Mallari, N. A. D. and Marsden, S. J. (2016) Large avian frugivores in the Philippines show linear responses to improvements in forest quality. Forest Ecol. Manag. 375: 127-133.

ESRI (2016) ArcGIS v.10.4. Available at: https://www.esri.com/en-us/arcgis/aboutarcgis/overview [accessed 26 October 2018].

Falcidia, M. (2017) A faunal inventory of rare, elusive and cryptic species, Southern Negros, Philippines: A camera trap study. MSc thesis. Bristol, UK: University of Bristol.

Feld, C. K., Segurado, P. and Gutiérrez-Cánovas, C. (2016) Analysing the impact of multiple stressors in aquatic biomonitoring data: a 'cookbook' with applications in R. Sci. Total Environ. 573: 1320-1339.
Fielding, A. H. and Bell, J. F. (1997) A review of methods for the assessment of prediction errors in conservation presence/absence models. Environ. Conserv. 24: 38-49.

Flinn Scientific (2016) How tall is that tree? Available at: https://www.flinnsci.ca/api/ library/Download/98bc4c5dde564bi48do 0234333 eeg762 [accessed 26 August 2020].

Food and Agriculture Organization of the United Nations (2015) Global Forest Resources Assessment 2015. Rome, Italy: Food and Agriculture Organization of the United Nations. Available at: http://www. econis.eu/PPNSET?PPN=835454703 [accessed 20 March 2018].

Foundation for the Philippine Environment (2018) Northwest Panay Peninsula. Available at: https://fpe.ph/conservation_site/ location_details/northwest-panay-penin sula [accessed 26 October 2018].

Gaworecki, M. (2018) Footage of elusive Negros Bleeding-heart Dove captured in the wild. Available at: https://news.mongabay.com/2018/06/footage-of-elusivenegros-bleeding-heart-dove-captured-inthe-wild/ [accessed 16 November 2018].

Gómez-Sánchez, D., Olalde, I., Sastre, N., Enseñat, C., Carrasco, R., Marques-Bonet, T., Lalueza-Fox, C., Leonard, J.A., Vilà, C. and Ramírez, O. (2018) On the path to extinction: inbreeding and admixture in a declining Grey wolf population. Mol. Ecol. 27: 3599-3612.

Hamann, A. (2002) The North Negros Forest Reserve: a biodiversity hotspot at risk. Silliman Journal 43: 83-90.

Hansen, M. C., Potapov, P. V., Moore, R., Hancher, M., Turubanova, S. A., Tyukavina, A., Thau, D., Stehman, S. V., Goetz, S. J., Loveland, T. R., Kommareddy, A., Egorov, A., Chini, L., Justice, C. O. and Townshend, J. R. G. (2013) High-resolution global maps of 21st-century forest cover change. Science 342(6160): 850-853.

Haribon Foundation (2016) Critical habitat establishment: A conservation strategy to protect the mountain range of Central Panay. Available at: http://www.haribon. org.ph/index.php/news/item/183-criticalhabitat-establishment-a-conservation-strat egy-to-protect-the-mountain-range-of-cen tral-panay [accessed 20 November 2018]. 
Hof, A. R., Jansson, R. and Nilsson, C. (2012) The usefulness of elevation as a predictor variable in species distribution modelling. Ecol. Model. 246: 86-9o.

Huon, M., Jones, E. L., Matthiopoulos, J., McConnell, B., Caurant, F. and Vincent, C. (2015) Habitat selection of gray seals (Halichoerus grypus) in a marine protected area in France. J. Wildl. Manag. 79: 1091-1100.

Jansen, A. (2005) Avian use of restoration plantings along a creek linking rainforest patches on the Atherton Tablelands, North Queensland. Restor. Ecol. 13: 275-283.

Kramer, A., Dennis, B., Liebhold, A. and Drake, J. (2009) The evidence for Allee effects. Popul. Ecol. 51: 341-354.

Lahoz-Monfort, J. J., Guillera-Arroita, G. and Wintle, B. A. (2014) Imperfect detection impacts the performance of species distribution models. Glob. Ecol. Biogeogr. 23: 504-515.

Lee, D. C. and Marsden, S. J. (2008) Adjusting count period strategies to improve the accuracy of forest bird abundance estimates from point transect distance sampling surveys. Ibis 150: $315-325$.

Lee, D. K., Hyun, J. O. and Kang, H. S. (2012) National forest assessment report. Seoul, The Republic of Korea: ASEAN-Korea Environmental Cooperation Unit.

Lewis, C. T., Melo, M., de Lima, R. F. and Bremner-Harrison, F. (2018) Habitat associations of the Critically Endangered São Tomé Fiscal Lanius newtoni: comparing standard and playback-confirmed point counts. Afr. J. Ecol. 56: 404-408.

Lima, S. L. and Dill, L. M. (1990) Behavioral decisions made under the risk of predation: a review and prospectus. Can. J. Zool. 68: 619-640.

Liu, C., Berry, P. M., Dawson, T. P., Pearson, R. G. (2005) Selecting thresholds of occurrence in the prediction of species distributions. Ecography 28: 385-393.

Lloyd, H., Cahill, A., Jones, M. and Marsden, S. (2000) Estimating bird densities using distance sampling. Pp. $35-52$ in C. Bibby, M. Jones and S. Marsden, eds. Bird Surveys. Cambridge, UK: BirdLife International.

Masur, D. (2010) Vorläufiger Bericht: Transektbegehung in der, Central Panay MountainRange (CPMR), Makrozoologischer Teil.
Unpublished report. Antique, Philippines: PhilinCon.

Meijaard, E., Oliver, W. R. T. and Leus, K. (2017) Sus cebifrons. In The IUCN Red List of Threatened Species 2017. Available at: http://dx.doi.org/10.2305/IUCN.UK.20173.RLTS.T21175A44139575.en [accessed 26 October 2018].

Merow, C., Smith, M. J. and Silander, J. A. (2013) A practical guide to MaxEnt for modeling species' distributions: what it does, and why inputs and settings matter. Ecography 36: 1058-1069.

Morales, N. S., Fernández, I. C. and BacaGonzález, V. (2017) MaxEnt's parameter configuration and small samples: are we paying attention to recommendations? A systematic review. PeerJ 5: e3093.

Neate-Clegg, M. H. C., Morshuis, E. C. and Banks-Leite, C. (2016) Edge effects in the avifaunal community of riparian rain-forest tracts in tropical North Queensland. J. Trop. Ecol. 32: 280-289.

Newmark, W. D., Mkongewa, V. J. and Sobek, A. D. (2010) Ranging behavior and habitat selection of terrestrial insectivorous birds in north-east Tanzania: implications for corridor design in the Eastern Arc Mountains. Anim. Conserv. 13: 474-482.

O'Brien, R. M. (2007) A caution regarding rules of thumb for variance inflation factors. Qual. Quant. 41: 673-69o.

Pangau-Adam, M., Mühlenberg, M. and Waltert, M. (2015) Rainforest disturbance affects population density of the Northern cassowary Casuarius unappendiculatus in Papua, Indonesia. Oryx 49: 735.

Paz, S. L., Ngoprasert, D., Nuneza, O. M., Mallari, N. A. D. and Gale, G. A. (2013) Philippine-endemic and Mindanaoendemic bird communities on Canticol and Mt. Hilong-hilong, Philippines. Asian J. Biodivers. 4: 136-168.

Pedregosa-Hospodarsky, M. (2008) Developing field research priorities in Negros and Panay Islands (West Visayas, Philippines) with particular reference to key threatened endemic species. Available at: https://www.rufford. org/files/Developing \% 20Field\% 20Research $\%$ 2oPriorities \% 20in \% 20Negros \% 20and $\%$ 2oPanay\% 20Islands \% 20(West \% 20Visayas, \% 2oPhilippines), \% 2owith \% 2oparticular \% 
2oreference $\%$ 20to \% 20key.pdf [accessed 20 November 2018].

Pedregosa-Hospodarsky, M., Hospodarsky, P., Castro, D., Jose, P. F. S., Abalajon, J. M., Alpas, R. and Perez, L. J. (2009) A faunal assessment of the North Negros Natural Park (NNNP) Negros Island, Philippines. Available at: https://www.rufford.org/ files/47.09.07\% 20Detailed \% 20Final\% 20Report.pdf [accessed 20 November 2018].

Peh, K. S., Jong, J. d., Sodhi, N. S., Lim, S. L. and Yap, C. A. (2005) Lowland rainforest avifauna and human disturbance: persistence of primary forest birds in selectively logged forests and mixed-rural habitats of southern Peninsular Malaysia. Biol. Conserv. 123: 489-505.

Peh, K. S., Sodhi, N. S., de Jong, J., Sekercioglu, C. H., Yap, C. A. and Lim, S. L. (2006) Conservation value of degraded habitats for forest birds in southern Peninsular Malaysia. Divers. Distrib. 12: 572-581.

PhilGIS (2007) SRTM DEM (Shuttle Radar Topography Mission - Digital Elevation Model). Available at: http://philgis.org/ country-basemaps/srtm-dem-shuttleradar-topography-mission-digital-eleva tion-model [accessed 12 November 2018].

PhilinCon (2018) NW Panay Peninsula Natural Park. Available at: https://philincon. de/home/northwest-panay-peninsula-natu ral-park/ [accessed 31 July 2019].

Phillips, S. J. and Dudík, M. (2008) Modeling of species distributions with Maxent: new extensions and a comprehensive evaluation. Ecography 31: 161-175.

Phillips, S. J., Dudík, M. and Schapire, R. E. (2017) Maxent software for modeling species niches and distributions (Version 3.4.1). Available at: http://biodiversityinformatics. amnh.org/open_source/maxent/ [accessed 12 November 2018].

Pohlman, C. L., Turton, S. M. and Goosem, M. (2007) Edge effects of linear canopy openings on tropical rain forest understory microclimate. Biotropica 39: 62-71.

Posa, M. R. C. and Sodhi, N. S. (2006) Effects of anthropogenic land use on forest birds and butterflies in Subic Bay, Philippines. Biol. Conserv. 129: 256-270.

Poulsen, M. K. and Lambert, F. R. (2000) Altitudinal distribution and habitat preferences of forest birds on Halmahera and Buru, Indonesia: implications for conservation of Moluccan avifaunas. Ibis 142 : 566-586.

Powell, L. L., Stouffer, P. C. and Johnson, E. I. (2013) Recovery of understory bird movement across the interface of primary and secondary Amazon rainforest. Auk 130: 459-468.

$\mathrm{R}$ Core Team (2019) R: A language and environment for statistical computing, Version 3.6.1. Vienna, Austria: R Foundation for Statistical Computing.

Radosavljevic, A. and Anderson, R. P. (2014) Making better Maxent models of species distributions: complexity, overfitting and evaluation. J. Biogeogr. 41: 629-643.

Reid, J. L., Harris, J. B. C. and Zahawi, R. A. (2012) Avian habitat preference in tropical forest restoration in southern Costa Rica. Biotropica 44: 350-359.

Reid, S., Díaz, I. A., Armesto, J. J. and Willson, M. F. (2004) Importance of native bamboo for understory birds in Chilean temperate forests. Auk 121: 515-525.

Rivera-Milán, F. F., Bertuol, P., Simal, F. and Rusk, B. L. (2015) Distance sampling survey and abundance estimation of the Critically Endangered Grenada dove (Leptotila wellsi). Condor 117: 87-93.

Rowcliffe, J. M., Carbone, C., Jansen, P. A., Kays, R. and Kranstauber, B. (2011) Quantifying the sensitivity of camera traps: an adapted distance sampling approach. Methods in Ecol. Evol. 2: 464-476.

Schwarz, C. (2014) Results of the two biodiversity surveys conducted for the ForClimPanay Project during the year 2013. Antique, Philippines: Philippine Initiative for Conservation of Environment and the People (PhilinCon).

Shoo, L. P., Freebody, K., Kanowski, J. and Catterall, C. P. (2016) Slow recovery of tropical old-field rainforest regrowth and the value and limitations of active restoration. Conserv. Biol. 30: 121-132.

Sieving, K. E., Willson, M. F. and De Santo, T. L. (1996) Habitat barriers to movement of understory birds in fragmented southtemperate rainforest. Auk 113: 944-949.

Slade, E. M., Villanueva, J. F., Tacud, B. and Curio, E. (2005) First nesting observations of the Negros bleeding-heart Gallicolumba 
keayi from Panay, Philippines. Forktail 21: 161-163.

Smith, D. A. E., Smith, Y. C. E. and Downs, C. T. (2017) Seasonal habitat requirements of Lemon dove (Aplopelia larvata) in coastal forest: camera-trap surveys of a reclusive species. Afr. Zool. 52: 199-207.

Spigler, R. B., Theodorou, K. and Chang, S. (2017) Inbreeding depression and drift load in small populations at demographic disequilibrium. Evolution 71: 81-94.

Steadman, D. W. and Freifeld, H. B. (1998) Distribution, relative abundance, and habitat relationships of landbirds in the Vava'u Group, Kingdom of Tonga. Condor 100: 609-628.

Stratford, J. A. and Stouffer, P. C. (2013) Microhabitat associations of terrestrial insectivorous birds in Amazonian rainforest and secondgrowth forests. J. Field Ornithol. 84: 1-12.

Tesoro, F. O. (2002) Rattan resources of the Philippines: their extent, production, utilization and issues on resource development. Pp. $167-182$ in D. Dransfield, F. O. Tesoro and N. Manokaran, eds. Rattan: Current research issues and prospects for conservation and sustainable development. Rome, Italy: Food and Agriculture Organisation of the United Nations.

Treves, A., Mwima, P., Plumptre, A. J. and Isoke, S. (2010) Camera-trapping forestwoodland wildlife of western Uganda reveals how gregariousness biases estimates of relative abundance and distribution. Biol. Conserv. 143: 521-528.

Walker, J. S. (2007) Geographical patterns of threat among pigeons and doves (Columbidae). Oryx 41: 289-299.

$\mathrm{Xu}$, Y., Lin, S., He, J. Xin, Y., Zhang, L, Jiang, H. and Li, Y. (2017) Tropical birds are declining in the Hainan Island of China. Biol. Conserv. 210: 9-18.

Zabal, B. R. B. (2014) Bill on Panay Peninsula as Protected Area Ok'd. Panay News, Panay, Philippines. Available at: https://www.pan aynews.net/bill-on-panay-peninsula-asprotected-area-okd/ [accessed 26 October 2018].

Zarones, L., Colon, M. R., Ha, J. C. and Ha, R. R. (2013) Effects of foliage invertebrate availability and forest structure on the abundance of the Critically Endangered Rota white-eye Zosterops rotensis in Rota, Mariana Islands. Bird Conserv. Internatn. 23: 454-462.

Zhao, Q., Zhang, H. and Wei, J. (2019) Climatic niche comparison across a cryptic species complex. PeerJ 7: e7042.

Zuur, A. F., Hilbe, J. and Ieno, E. N. (2013) $A$ beginner's guide to GLM and GLMM with R. Newburgh, UK: Highland Statistics.

Zuur, A. F., Ieno, E. N. and Elphick, C. S. (2010) A protocol for data exploration to avoid common statistical problems. Methods in Ecol. Evol. 1: 3-14. 